Article

\title{
Simulation Study to Investigate the Effects of Operational Conditions on Methylcyclohexane Dehydrogenation for Hydrogen Production
}

\author{
Muhammad Haris Hamayun ${ }^{1}\left(\mathbb{D}\right.$, Ibrahim M. Maafa ${ }^{2, *}$, Murid Hussain ${ }^{1, *(1)}$ and Rabya Aslam ${ }^{3}$ (1) \\ 1 Department of Chemical Engineering, COMSATS University Islamabad, Lahore Campus, Defence Road, \\ Off-Raiwind Road, Lahore 54000, Pakistan; mhhamayun@cuilahore.edu.pk \\ 2 Department of Chemical Engineering, College of Engineering, Jazan University, Jazan 45142, Saudi Arabia \\ 3 Institute of Chemical Engineering and Technology, University of the Punjab, New Campus, Lahore 54590, \\ Pakistan; rabya.icet@pu.edu.pk \\ * Correspondence: imoaafa@jazanu.edu.sa (I.M.M.); drmhussain@cuilahore.edu.pk (M.H.)
}

Received: 29 November 2019; Accepted: 30 December 2019; Published: 1 January 2020

check for updates

\begin{abstract}
In the recent era, hydrogen has gained immense consideration as a clean-energy carrier. Its storage is, however, still the main hurdle in the implementation of a hydrogen-based clean economy. Liquid organic hydrogen carriers (LOHCs) are a potential option for hydrogen storage in ambient conditions, and can contribute to the clean-fuel concept in the future. In the present work, a parametric and simulation study was carried out for the storage and release of hydrogen for the methylcyclohexane toluene system. In particular, the methylcyclohexane dehydrogenation reaction is investigated over six potential catalysts for the temperature range of $300-450{ }^{\circ} \mathrm{C}$ and a pressure range of 1-3 bar to select the best catalyst under optimum operating conditions. Moreover, the effects of hydrogen addition in the feed mixture, and byproduct yield, are also studied as functions of operating conditions. The best catalyst selected for the process is $1 \mathrm{wt}$. $\% \mathrm{Pt} / \gamma-\mathrm{Al}_{2} \mathrm{O}_{3}$. The optimum operating conditions selected for the dehydrogenation process are $360^{\circ} \mathrm{C}$ and 1.8 bar. Hydrogen addition in the feed reduces the percentage of methylcyclohexane conversion but is required to enhance the catalyst's stability. Aspen HYSYS v. 9.0 (AspenTech, Lahore, Pakistan) has been used to carry out the simulation study.
\end{abstract}

Keywords: LOHC; simulation; methylcyclohexane; dehydrogenation; Aspen HYSYS; energy

\section{Introduction}

Conventional fuel-based power generation systems are the major contributors to air pollution in the modern era. Researchers all over the world are in the continuous effort to introduce environmentally friendly fuels not only to cope up with this issue but also to fulfill the future fuel demand. Over the years, various solutions have been projected to assuage ecological impairment and future fuel deficiency. Onboard hydrogen storage is one of those viable solutions which propose hydrogen usage as a fuel in proton-exchange membrane (PEM) fuel cells, hydrogen-fired gas turbines, or in internal combustion engines [1-3]. The hydrogen-based energy system has potential as a future fuel, as in comparison to other available fuels, hydrogen has maximum energy per unit mass, i.e., $119 \mathrm{~kJ} / \mathrm{gm}$ at normal temperature and pressure (NTP), with no greenhouse gases as the product of combustion. The global environmental index for various fuels is presented in Table 1, which shows that hydrogen as a fuel is comparatively cleaner than various fossil fuels [4]. 
Table 1. Global environmental index for various fuels (Adapted from [4]).

\begin{tabular}{cc}
\hline Fuel & Environmental Impact $\left(\mathbf{i}_{\text {env }}\right)$ \\
\hline \multirow{2}{*}{ Hydrogen } & 0.95 (no water) \\
& 0.45 \\
Coal & 0.82 (no water) \\
& 0.78 \\
Gasoline & 0.76 (no water) \\
& 0.72 \\
Methane & 0.90 (no water) \\
& 0.80 \\
\hline
\end{tabular}

Water is not included as it is not considered as a pollutant in the post-combustion process.

However, chemically, hydrogen is not available freely like other fossil fuels, so it is considered as the carrier of energy, not as a fuel [1,5]. The problems associated with the hydrogen system is its storage and transportation [1,2]. Various techniques are under investigation for the advancement of a cost-effective and safe system for the efficient storage of hydrogen, such as liquefaction, compression, absorption in a metal-organic framework, nanotubes, etc. Among others, liquid organic hydrogen carriers (LOHCs) are the compounds (mainly aromatics) that can be used to store and transport hydrogen (4-7 wt. \%) via reversible reactions of hydrogenation and dehydrogenation. This concept provides a solution towards the implementation of a sustainable and efficient hydrogen-based economy, i.e., the solution to the transportation and storage problems of hydrogen [2,3,6]. A comparison of energy and cost assessments of various hydrogen-storage techniques is presented in Table 2 [3].

Table 2. Energy and cost demands of hydrogen-storage systems (Adapted from [3]).

\begin{tabular}{ccccc}
\hline Description & Unit & $\begin{array}{c}\text { Liquid Organic } \\
\text { Hydrogen Carriers }\end{array}$ & $\begin{array}{c}\text { Compressed } \\
\text { Hydrogen Storage }\end{array}$ & $\begin{array}{c}\text { Liquid Hydrogen } \\
\text { Storage }\end{array}$ \\
\hline Energy Demand & $\mathrm{kWh}_{\mathrm{x}} / \mathrm{kWh}_{\text {hyd }}$ & $1.1 \%$ & $3.5 \%$ & $21 \%$ \\
Cost Estimation & $€ / \mathrm{kg} \mathrm{hydrogen}^{\mathrm{a}}$ & 0.238 & 0.243 & 0.732 \\
\hline
\end{tabular}

${ }^{a}$ Depreciation cost + Electricity cost + Operating expenses + Catalyst cost + substitution of LOHC material.

Energy consumption takes place during the processing, storage, and transportation of hydrogen, and must be considered in the calculations of the energetic efficiency of the system. The energy consumption can also be termed as energy loss/waste heat, which cannot be regained economically [3].

Among the various $\mathrm{H}_{2}$ storage techniques, three potential candidates, i.e., $\mathrm{LOHC}(\mathrm{MCH}$-toluene system), $\mathrm{NH}_{3}$, and Liquid $\mathrm{H}_{2}$ have been compared. The comparison has been presented in Table 3 [7].

Table 3. Comparison of various hydrogen-storage techniques [7].

\begin{tabular}{|c|c|c|c|}
\hline Characteristic & LOHC & Liquid $\mathrm{H}_{2}$ & Ammonia $\left(\mathrm{NH}_{3}\right)$ \\
\hline Purpose & $\begin{array}{l}\text { Dehydrogenation } \\
\text { followed by } \\
\text { hydrogen combustion. } \\
\text { Dehydrogenation and } \\
\text { purification followed } \\
\text { by utilization in the } \\
\text { fuel cell. }\end{array}$ & $\begin{array}{l}\text { - } \quad \text { Combustion of } \mathrm{H}_{2} \text {. } \\
\text { Utilization in the } \\
\text { fuel cell. }\end{array}$ & $\begin{array}{l}\text { - } \quad \text { Direct combustion } \\
\text { Hydrogenation and } \\
\text { purification followed } \\
\text { by utilization in the } \\
\text { fuel cell. } \\
\text { - Direct fuel cell. }\end{array}$ \\
\hline Infrastructure & $\begin{array}{l}\text { Opportunity to make } \\
\text { use of the currently } \\
\text { available } \\
\text { gasoline infrastructure. }\end{array}$ & $\begin{array}{l}\text { Needs further } \\
\text { development and } \\
\text { construction for a } \\
\text { large-scale system. }\end{array}$ & $\begin{array}{l}\text { Opportunity to make } \\
\text { use of the currently } \\
\text { available } \\
\text { propane infrastructure. }\end{array}$ \\
\hline
\end{tabular}


Table 3. Cont.

\begin{tabular}{|c|c|c|c|}
\hline Characteristic & LOHC & Liquid $\mathrm{H}_{2}$ & Ammonia $\left(\mathrm{NH}_{3}\right)$ \\
\hline $\begin{array}{l}\text { Auto-Ignition } \\
\text { Temperature }\end{array}$ & - $\quad 283^{\circ} \mathrm{C}$ & - $\quad 535^{\circ} \mathrm{C}$ & - $\quad 651^{\circ} \mathrm{C}$ \\
\hline Advantages & $\begin{array}{l}\text { Storage in liquid } \\
\text { condition is possible } \\
\text { (minimum loss during } \\
\text { transportation). } \\
\text { Established } \\
\text { infrastructure can be } \\
\text { used for storage. } \\
\text { Storage can be done } \\
\text { under } \\
\text { existing regulations }\end{array}$ & $\begin{array}{ll}\text { - } & \text { High purity. } \\
\text { Requires no } \\
\text { dehydrogenation } \\
\text { and purification. }\end{array}$ & $\begin{array}{ll}\text { - } & \text { Cheapest } \\
\text { energy carrier. } \\
\text { - } \quad \text { Direct use is possible. } \\
\text { Established } \\
\text { infrastructure can be } \\
\text { used for storage. } \\
\text { - Storage can be done } \\
\text { under } \\
\text { existing regulations }\end{array}$ \\
\hline Challenges & 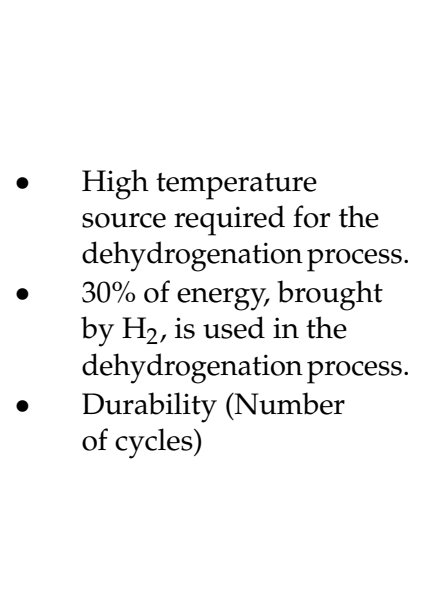 & 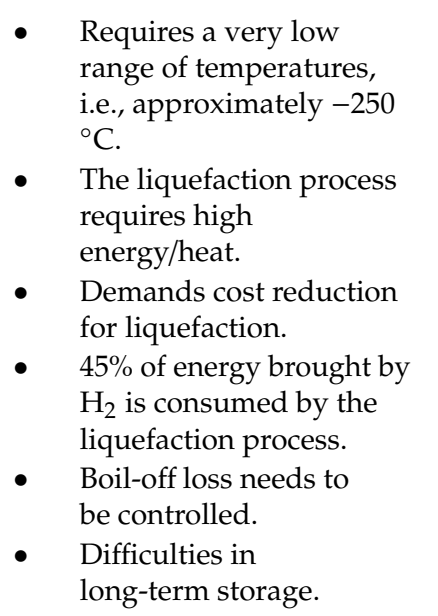 & $\begin{array}{l}\text { - Compared to } \\
\text { hydrocarbons, } \mathrm{NH}_{3} \text { has } \\
\text { lower reactivity. } \\
\text { Treatment required by } \\
\text { certified Engineers, } \\
\text { because of pungent } \\
\text { smell and toxicity. } \\
13 \% \text { of energy brought } \\
\text { by } \mathrm{H}_{2} \text { is consumed in } \\
\text { the dehydrogenation } \\
\text { and } \\
\text { purification processes. }\end{array}$ \\
\hline $\begin{array}{l}\text { Development } \\
\text { Stage }\end{array}$ & - Demonstration stage & $\begin{array}{ll}\text { - Small scale: } \\
\text { application stage } \\
\text { - } \quad \text { Large scale: Setup } \\
\text { under development. }\end{array}$ & $\begin{array}{l}\text { Research and } \\
\text { development stage } \\
\text { Partly has entered } \\
\text { demonstration stage. }\end{array}$ \\
\hline Prospects & $\begin{array}{ll}\text { - } & \text { Energy } \\
\text { efficient dehydrogenation. } \\
\text { - Catalysts for } \\
\text { dehydrogenation and } \\
\text { hydrogenation processes. }\end{array}$ & $\begin{array}{l}\text { Liquefaction process } \\
\text { required improvement in } \\
\text { energy efficiency. } \\
\text { Regulations for } \\
\text { transportation, } \\
\text { loading/unloading systems. }\end{array}$ & $\begin{array}{l}\text { - Fuel cell with direct } \\
\mathrm{NH}_{3} \text {. } \\
\text { - High energy efficiency } \\
\text { in the synthesis stage. }\end{array}$ \\
\hline
\end{tabular}

The gravimetric density of liquid $\mathrm{H}_{2}$ is highest, followed by $\mathrm{NH}_{3}$ and LOHC. For the storage of hydrogen through $\mathrm{NH}_{3}, \mathrm{MCH}$ and Liquid $\mathrm{H}_{2}$, existing infrastructure along with established rules and regulations are developed. The regeneration temperatures required for the $\mathrm{NH}_{3}$ system are in the range of $400-500{ }^{\circ} \mathrm{C}$, compared with $100-200{ }^{\circ} \mathrm{C}$ for the LOHC system. Therefore, LOHC has been termed as an efficient technique, as it is comparatively the most established and efficient technique [7].

Various systems exist under the umbrella of LOHC, the comparisons of which have been presented in Table 4 [7-9]. The comparison shows that despite the lower gravimetric and volumetric densities of the $\mathrm{MCH}$-toluene system, this system has better applicability due to the following reasons, among others: 
- $\mathrm{MCH}$ and toluene exist in liquid form, and have no handling issues, unlike the naphthalene-decalin system, in which naphthalene exists in a solid state, thus causing handling issues, making this system unfavorable for operation.

- Comparatively, benzene is more toxic than methylcyclohexane. As reported by US health exposure limits (NIOSH), the permissible exposure limit of benzene is $1 \mathrm{ppm}$ and methylcyclohexane is 500 ppm. An exposure limit of $500 \mathrm{ppm}$ of benzene causes immediate danger, while $1200 \mathrm{ppm}$ of $\mathrm{MCH}$ does the same.

- The dibenzyl toluene-perhydro-dibenzyl toluene (DBT-PBT) system has a higher energy requirement for the dehydrogenation process as compared to the methylcyclohexanetoluene-hydrogen (MTH) system, making this system unfavorable for operation [3,7,10-13].

Table 4. Comparison of various liquid organic hydrogen carriers (LOHCs) for hydrogen storage [7-9].

\begin{tabular}{|c|c|c|c|c|}
\hline Characteristics & $\begin{array}{c}\text { Benzene-Cyclohexane } \\
\text { System }\end{array}$ & $\begin{array}{l}\text { Naphthalene-Decalin } \\
\text { System }\end{array}$ & $\begin{array}{l}\text { DBT-PDBT } \\
\text { System }\end{array}$ & $\begin{array}{l}\text { MCH-Toluene } \\
\text { System }\end{array}$ \\
\hline $\begin{array}{l}\text { Phase under } \\
\text { ambient conditions }\end{array}$ & Liquid & Solid + Liquid & Liquid & Liquid \\
\hline Temperature $\left({ }^{\circ} \mathrm{C}\right)$ & $150-250$ & $150-250$ & 180 & $200-300$ \\
\hline Pressure (bar) & $10-50$ & $20-50$ & $10-50$ & $10-50$ \\
\hline $\begin{array}{c}\text { Volumetric } \mathrm{H}_{2} \\
\text { density } \\
\left(\mathrm{kg}-\mathrm{H}_{2} \cdot \mathrm{m}^{-3}\right)\end{array}$ & 55.9 & 65.4 & 57 & 47.4 \\
\hline $\begin{array}{l}\text { Gravimetric } \mathrm{H}_{2} \\
\text { density (wt. \%) }\end{array}$ & 7.20 & 7.29 & 6.2 & 6.16 \\
\hline $\begin{array}{l}\text { Heat of reaction } \\
\qquad\left(\mathrm{kJ} \cdot \mathrm{mol}^{-1}\right)\end{array}$ & 205.9 & 319.5 & 588.5 & 204.8 \\
\hline Challenges & $\begin{array}{l}\text { High melting point } \\
\text { and toxicity }\end{array}$ & $\begin{array}{l}\text { Dehydrogenation } \\
\text { process requires } \\
\text { high energy } \\
\text { consumption, solid } \\
\text { in nature, difficult } \\
\text { handling. }\end{array}$ & $\begin{array}{l}\text { Dehydrogenation } \\
\text { process requires } \\
\text { high energy } \\
\text { consumption. }\end{array}$ & $\begin{array}{l}\text { Volatile and } \\
\text { inflammable. }\end{array}$ \\
\hline
\end{tabular}

An overall LOHC system comprises reversible cycle hydrogenation and dehydrogenation for storage and release of hydrogen respectively. Although hydrogenation is achieved with good efficiency ( $98 \%$ efficiency), still the dehydrogenation or unloading step is a major hurdle in this process [14].

Various researchers conducted the experimental work to investigate the methylcyclohexane dehydrogenation and byproducts formation rate using various catalysts. Taube et al. initially suggested technical parameters for the development of the MTH system for internal combustion engines [15]. Jothimurugesan et al., used $0.3 \mathrm{wt}$. \% Pt-Re/Alumina catalyst. The Langmuir-HinshelwoodHougen-Watson (LHHW) model was found to be the best fit for the studied system. A 98.2\% $\mathrm{MCH}$ conversion rate was achieved during the operation [16]. Mizsey et al., used a sulfided, reforming catalyst on a spherical alumina support, and achieved $98 \% \mathrm{MCH}$ conversion on the pilot plant scale system [17]. Usman et al., used $0.3 \mathrm{wt}$. \% $\mathrm{Pt} / \mathrm{Al}_{2} \mathrm{O}_{3}$ catalyst based on the power law kinetic model, and reported $97.5 \%$ conversion of $\mathrm{MCH}$ conversion in the absence of hydrogen [18]. Usman et al., used $1 \mathrm{wt}$. \% Pt $/ \theta-\mathrm{Al}_{2} \mathrm{O}_{3}$ catalyst, based on the power law and LHHW models and concluded that the LHHW model is the best fit for the system with this catalyst. Hydrogen addition in the feed promoted the dehydrogenation rate and reported a $\mathrm{MCH}$ conversion of $99.3 \%$ [19]. Usman et al., used $1 \mathrm{wt} . \%$ $\mathrm{Pt} /$ zeolite beta catalyst for both hydrogenation and dehydrogenation systems, and reported that $\%$ conversion of $\mathrm{MCH}$ was not clean, i.e., there was a high rate of byproduct formation. The authors reported $\mathrm{MCH}$ conversion of $83.32 \%$ for the dehydrogenation system, while $90.93 \%$ conversion was 
reported for the hydrogenation system [20,21]. Usman et al., used $1 \mathrm{wt}$. $\% \mathrm{Pt} / \gamma-\mathrm{Al}_{2} \mathrm{O}_{3}$ catalyst, and reported a $\mathrm{MCH}$ conversion rate of $97 \%$ [22]. Usman et al. studied $\mathrm{MCH}$ dehydrogenation using a catalytic fixed-bed reactor to determine the selectivity and activity of the various catalysts. Percentage of $\mathrm{MCH}$ conversion using various catalysts is summarized in Table 5 [20]. Chen et al. designed and optimized the catalytic membrane reactor for $\mathrm{MCH}$ dehydrogenation to produce hydrogen [23]. Wang et al., carried out $\mathrm{MCH}$ dehydrogenation using $\mathrm{Pt} / \mathrm{Ce}-\mathrm{Mg}-\mathrm{Al}-\mathrm{O}$ catalyst, and achieved a $\mathrm{MCH}$ conversion rate of $98.5 \%$ [24]. Obara carried out energy and exergy analysis of a complete hydrogen energy supply chain using $\mathrm{MCH}$ and reported the total efficiency to be $18 \%$ with a heat to power ratio of 0.931 [25].

Table 5. Catalyst comparison by Usman et al. (Adapted from [20]).

\begin{tabular}{ccc}
\hline Catalyst & MCH Conversion $\left(\mathbf{X}_{\mathbf{A}}\right) \mathbf{( \% )}$ & Byproduct Selectivity (\%) \\
\hline 1 wt.\% Pt $/ \gamma-\mathrm{Al}_{2} \mathrm{O}_{3}$ & 92 & 0.63 \\
1 wt. $\% \mathrm{Pt} / \theta-\mathrm{Al}_{2} \mathrm{O}_{3}$ & 91 & 0.10 \\
1 wt.\% Pt $/ \beta-z e o l i t e$ & 73 & 22.48 \\
20 wt. $\% \mathrm{Ni} / \gamma-\mathrm{Al}_{2} \mathrm{O}_{3}$ & 31 & 7.87 \\
\hline
\end{tabular}

The literature survey shows that the $\mathrm{MCH}$ dehydrogenation process has been examined experimentally by various researchers. However, simulation aspects have not been covered appropriately, i.e., the present literature shows that kinetic data has not been studied and conversion reactors have been used to present the dehydrogenation system. The performance of the dehydrogenation system is mainly dependent on temperature and pressure conditions, and the percentage of conversion changes with changes in operational conditions and use of suitable catalysts $[22,26,27]$. The rate of reaction is dependent on the properties of the catalyst, i.e., activity, selectivity and stability. Percentage of conversion increases with the increase in selectivity of the catalyst. Both activity and selectivity of the catalyst are dependent on the nuclearity of the support material. However, there exists a trade-off between activity and selectivity, which is dependent on the nuclearity of support material $[28,29]$. The optimum value of temperature and pressure promotes the reaction rate, thus increasing the percentage of conversion of the system. However, for the catalytic system, the optimum values of temperature and pressure have a direct relationship with the catalyst deactivation [30-32].

The present study intends to address this research gap by investigating methylcyclohexane dehydrogenation for the hydrogen release and storage, based on a simulation-parametric study. The six catalysts are investigated for the dehydrogenation system to select the best catalyst for the process, under the optimum operational conditions, i.e., temperature, pressure, and hydrogen concentration at the reactor inlet. Aspen HYSYS v. 9.0 has been used to carry out the simulation study.

\section{Simulation Study}

Aspen HYSYS v. 9.0 was used to carry out the simulation of the overall system. The complete schematic of the system is presented in Figure 1, out of which the dehydrogenation system has been taken for this study. The remaining system has been studied previously [33]. 


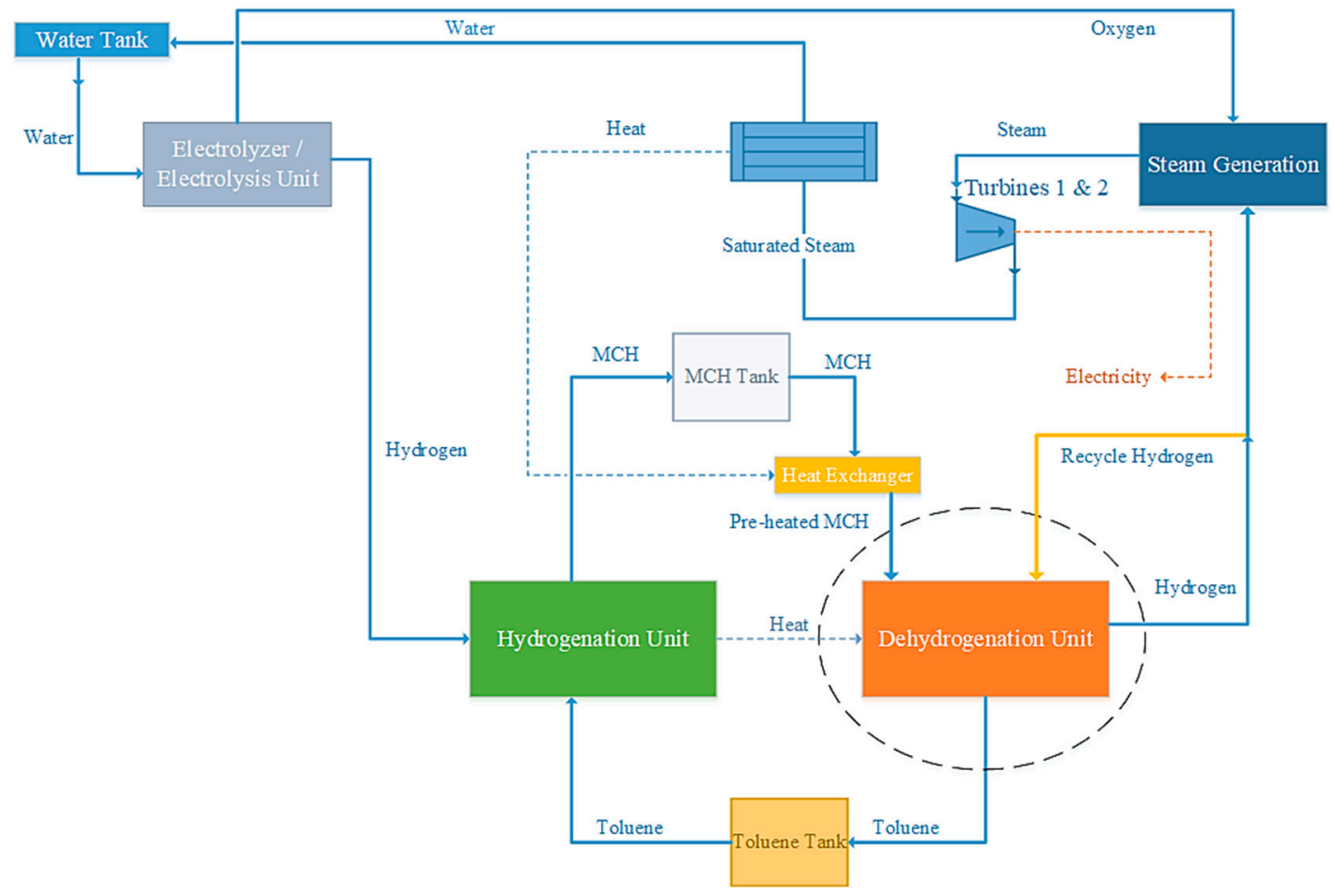

Figure 1. Overall schematic of the hydrogen-storage system (Adapted from [33]).

Methylcyclohexane and hydrogen are fed to the dehydrogenation reactor. The purpose of the addition of hydrogen in the feed is to enhance the stability of the catalyst. The types of the catalysts used is presented in Table 6.

Table 6. Catalysts used for the study.

\begin{tabular}{|c|c|c|c|c|}
\hline Sr. No. & Catalyst Type & Model & Kinetic Parameters & Reference \\
\hline Catalyst-1 & 0.3 wt. $\%$ commercial $\mathrm{Pt} / \mathrm{Al}_{2} \mathrm{O}_{3}$ & Power Law & $\begin{array}{c}k=1.65 \times 10^{-5} \\
E a=100.6\end{array}$ & [18] \\
\hline Catalyst-2 & $\begin{array}{l}\text { Commercial sulfided/spherical } \\
\text { alumina support }\end{array}$ & Power Law & $\begin{aligned} k= & 2.335 \times 10^{-6} \\
& E a=200\end{aligned}$ & [17] \\
\hline Catalyst-3 & 1 wt. $\% \mathrm{Pt} / \theta-\mathrm{Al}_{2} \mathrm{O}_{3}$ & LHHW & $\begin{array}{c}k=6.60 \times 10^{-5} \\
E a=50.2\end{array}$ & [19] \\
\hline Catalyst-4 & 1 wt. $\% \mathrm{Pt} / \beta$-Zeolite & $\begin{array}{c}\text { Power Law } \\
\text { LHHW }\end{array}$ & $\begin{array}{c}k=1.143 \times 10^{-5} \\
E a=6.0 \\
K^{\prime}=0.3088\end{array}$ & {$[21]$} \\
\hline Catalyst-5 & 1 wt. $\% \mathrm{Pt} / \gamma-\mathrm{Al}_{2} \mathrm{O}_{3}$ & LHHW & $\begin{array}{c}k=4.064 \times 10^{-5} \\
E a=54.55 \\
K^{\prime}=0.32\end{array}$ & [22] \\
\hline Catalyst-6 & 0.3 wt. $\% \mathrm{Pt}-\mathrm{Re} / \mathrm{Al}_{2} \mathrm{O}_{3}$ & Power Law & $\begin{array}{c}k=1.336 \times 10^{-5} \\
E a=51.9\end{array}$ & [16] \\
\hline
\end{tabular}

Units of $k=$ mols $^{-1}$ g-cat $^{-1} . \mathrm{Pa}, E a=\mathrm{kJ} / \mathrm{mol}, K=\mathrm{Pa}^{-3}$.

The overall process description is demonstrated in Figure 2. 


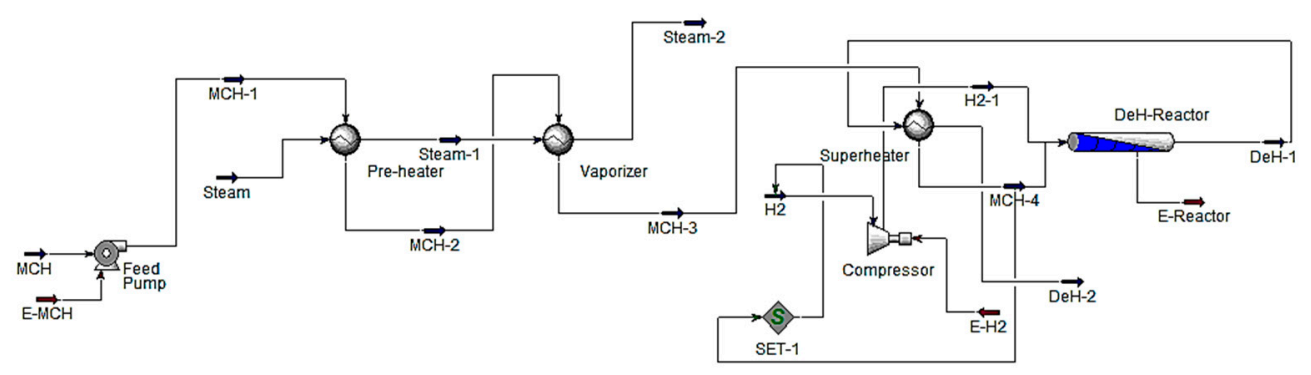

Figure 2. Process flow diagram of the methylcyclohexane dehydrogenation.

The reactor model assumed in Aspen HYSYS v. 9.0 is Plug Flow. Peng-Robinson has been used as the thermodynamic property package. The process initiates with the feed pump, which is used to supply methylcyclohexane to the dehydrogenation reactor. Feed pre-heating takes place before pumping, through the following routes:

- Pre-heater: heat is exchanged between methylcyclohexane (MCH-1) with saturated steam (Steam) from the exhaust of the extraction type steam turbine.

- Vaporizer: the methylcyclohexane (MCH-2) exchanges heat with steam (Steam-1) in the vaporizer.

- Superheater: the methylcyclohexane (MCH-3) exchanges heat with products of dehydrogenation reactor (DeH-1) to superheat the methylcyclohexane for the final pumping into the dehydrogenation reactor.

The methylcyclohexane (MCH-4) is fed to the dehydrogenation reactor (DeH-Reactor), where methylcyclohexane dehydrogenation to toluene and hydrogen is carried out using a suitable catalyst. The hydrogen addition is also done with the feed (after compression) to increase the catalyst stability and activity. Initially, the electrolysis section provides the hydrogen for the plant startup. Toluene and hydrogen production take place in the dehydrogenation reactor, which are separated using a separator. The separated hydrogen is fed/recycled to the dehydrogenation reactor (with methylcyclohexane) replacing hydrogen from the electrolysis section. The products of dehydrogenation reactor (DeH-1), after exchanging heat to methylcyclohexane (MCH-3) in the superheater (DeH-2), are sent to the separator for separation of hydrogen and other products. Part of the hydrogen is recycled, while part of the hydrogen is used to generate superheated steam (by reaction with oxygen in the steam generator). The superheated steam drives the steam turbine and the saturated steam (Steam) is used for pre-heating and vaporizing of the feed. The outlet steam (Steam-2) from the vaporizer is used in the different industrial processes.

The produced toluene is used for hydrogen storage in the hydrogenation reactor by reaction with hydrogen to yield methylcyclohexane. This reaction is highly exothermic and reaction heat is utilized to produce steam for power generation. The hydrogenation section is not considered in this study. The storage of the toluene is carried out at ambient temperature. Two main byproducts, i.e., cyclohexane and benzene, are considered in the study.

Operational conditions and catalysts are simultaneously varied in the simulation study to observe effect on the percentage of $\mathrm{MCH}$ conversion rate:

- $\quad$ Pressure range: 1-3 bars.

- Temperature range: $300-450{ }^{\circ} \mathrm{C}$.

- Concentration of hydrogen in the feed: $\mathrm{H}_{2} / \mathrm{MCH}$ ratio (by weight) at a value of 0 and 0.5 .

\section{Results}

The operating parameters are concurrently altered to determine the percentage of methylcyclohexane $(\mathrm{MCH})$ conversion for all the six catalysts used in the parametric study. The parametric study is done considering two cases: 
- $\mathrm{H}_{2} / \mathrm{MCH}$ ratio $=0$

- $\mathrm{H}_{2} / \mathrm{MCH}$ ratio $=0.5$

The $\mathrm{H}_{2} / \mathrm{MCH}$ ratio has been defined on weight ratio, and both $\mathrm{MCH}$ and $\mathrm{H}_{2}$ are feed into the dehydrogenation reactor in vapor form.

The effect of operational parameters on the methylcyclohexane conversion is presented in Figure 3 for the pressure of 1 bar and temperature range of $300-450{ }^{\circ} \mathrm{C}$. The trend suggests that catalyst- 3 and catalyst- 5 give the maximum $\% \mathrm{MCH}$ conversion, i.e., above $99 \%$, followed by catalyst-1, catalyst- 4 , catalyst-2, while catalyst- 1 provides the comparatively lowest percentage of $\mathrm{MCH}$ conversion, i.e., a maximum of $95 \%$ efficiency at $450{ }^{\circ} \mathrm{C}$.

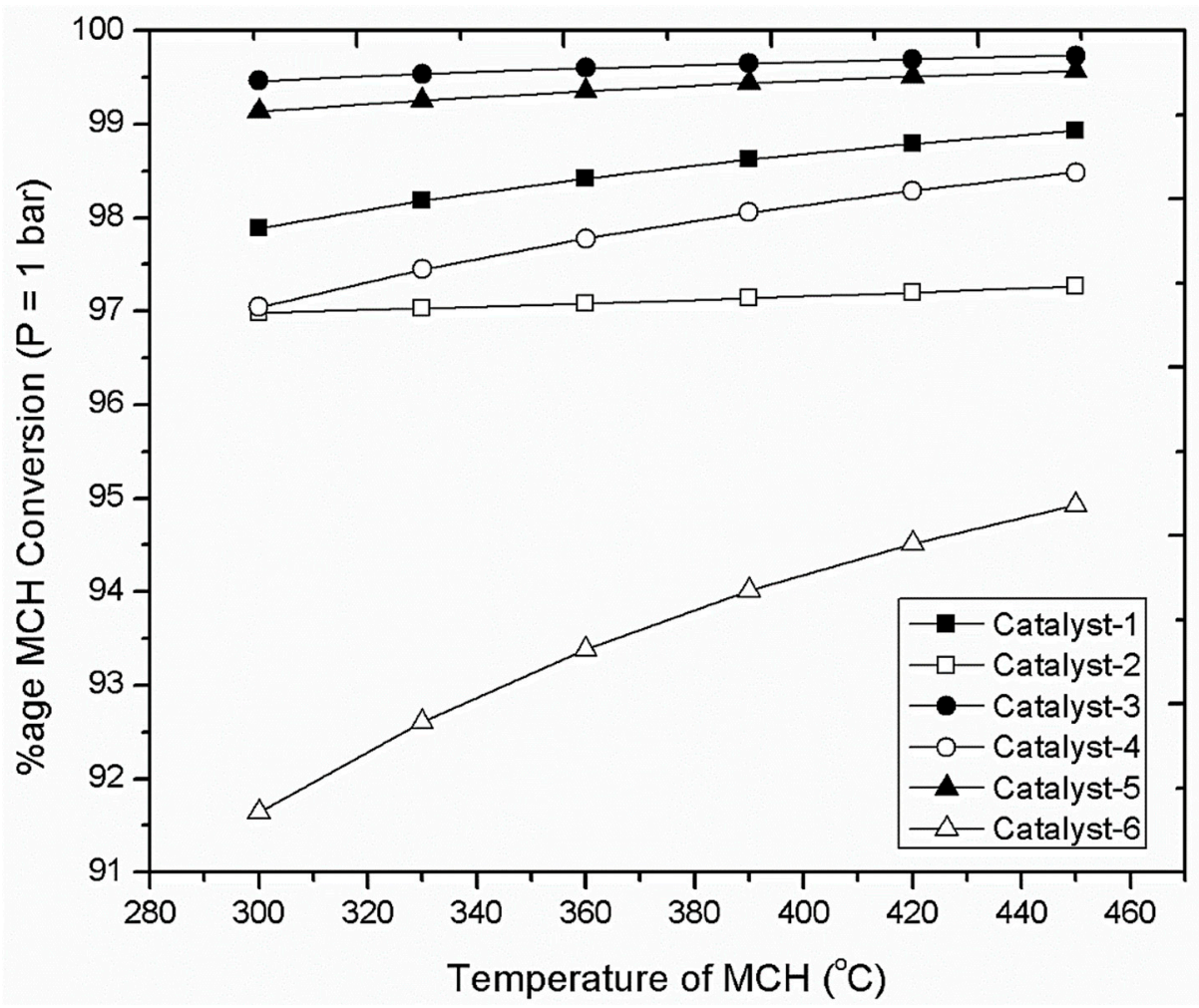

Figure 3. Effect of catalyst category on percentage of $\mathrm{MCH}$ conversion at $P=1$ bar, $\mathrm{H}_{2} / \mathrm{MCH}=0.5$.

The effect of operational parameters on the methylcyclohexane conversion is presented in Figure 4 for the pressure of $1.8 \mathrm{bar}$ and temperature range of $300-450{ }^{\circ} \mathrm{C}$. The trend is the same as for the operating pressure of 1 bar. However, in the temperature range of $420-450{ }^{\circ} \mathrm{C}$, the percentage of $\mathrm{MCH}$ conversion rate for catalyst- 2 is better than catalyst- 4 , and nearly the same as with catalyst-1, i.e., approximately $93 \%$ conversion in this temperature range.

The effect of operational parameters on the methylcyclohexane conversion is presented in Figure 5 for the pressure of 3 bars and temperature range of $300-450{ }^{\circ} \mathrm{C}$. Catalyst- 3 gives the highest percentage $\mathrm{MCH}$ conversion rate, i.e., a maximum of approximately $92 \%$ efficiency at $450{ }^{\circ} \mathrm{C}$. The percentage $\mathrm{MCH}$ conversion rates for catalyst- 5 and catalyst- 4 are comparable at this pressure value and temperature range. However, it remains below $90 \%$ even at a temperature of $450{ }^{\circ} \mathrm{C}$. Following these two catalysts, catalyst- 1 gives a maximum percentage conversion rate of approximately $78 \%$, catalyst- 6 gives a conversion rate of approximately $53 \%$, while catalyst-2 gives the lowest percentage $\mathrm{MCH}$ conversion rate, i.e., approximately $44 \%$. 


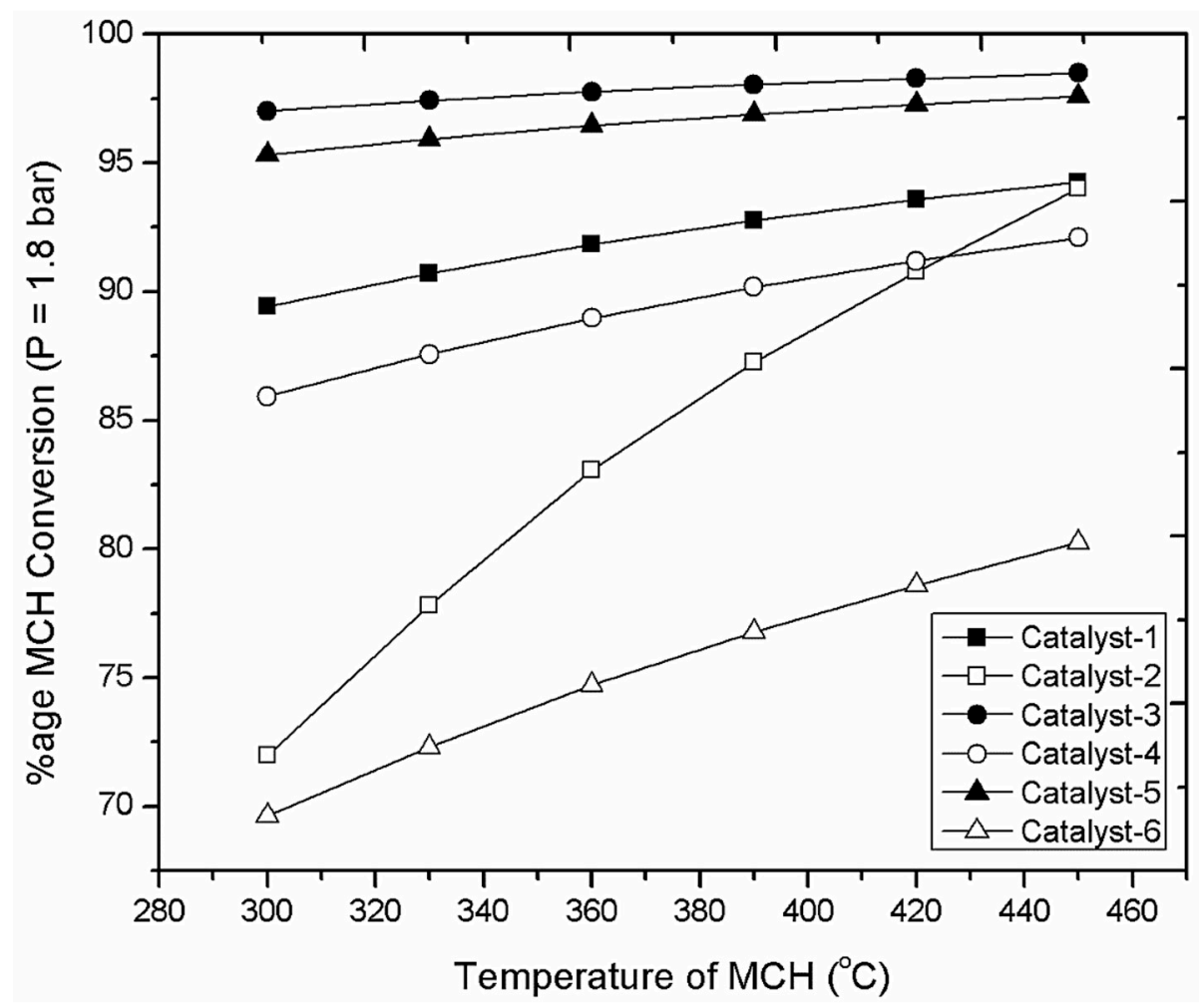

Figure 4. Effect of catalyst category on the percentage of $\mathrm{MCH}$ conversion at $P=1.8 \mathrm{bar}, \mathrm{H}_{2} / \mathrm{MCH}=0.5$.

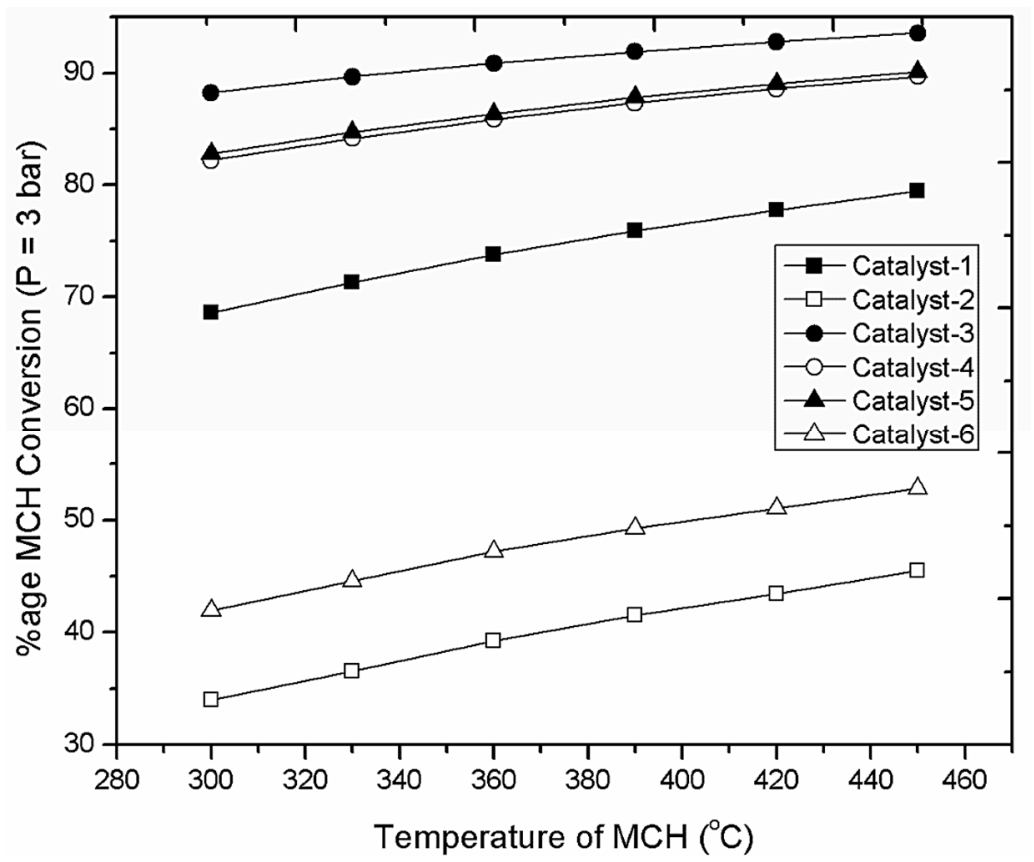

Figure 5. Effect of catalyst category on percentage of $\mathrm{MCH}$ conversion at $P=3$ bar, $\mathrm{H}_{2} / \mathrm{MCH}=0.5$.

The operating conditions are varied to determine the byproducts formation rate, especially with cyclohexane and benzene. Figure 6 reveals that with the increase in pressure or decrease in temperature of the dehydrogenation reactor feed, the byproducts formation rate increases, while the reverse trend is observed with a decrease in feed pressure of the dehydrogenation reactor, or with an increase in temperature. 


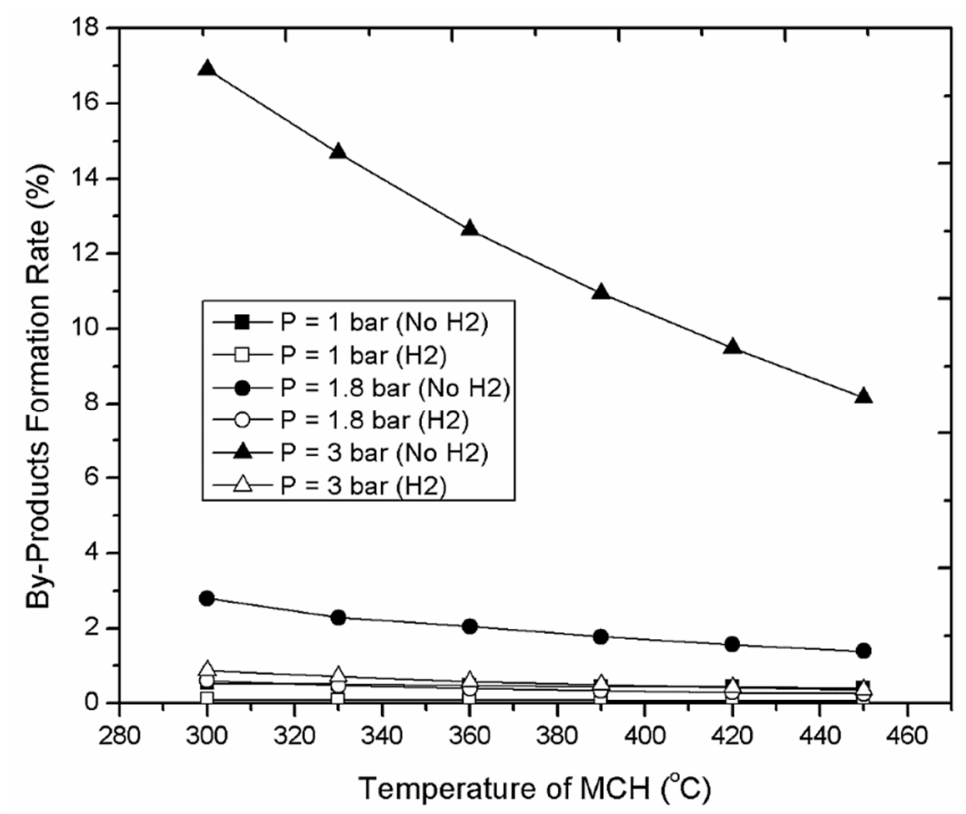

Figure 6. Effect of change in feed operating conditions on the byproducts' formation.

The main byproducts considered for the dehydrogenation reactor operation are cyclohexane and benzene. Figure 7 reveals that with the increase in pressure or decrease in temperature of the dehydrogenation reactor feed, the dehydrogenation of cyclohexane to benzene decreases, so at high pressure or low temperature, the cyclohexane is the main byproduct.

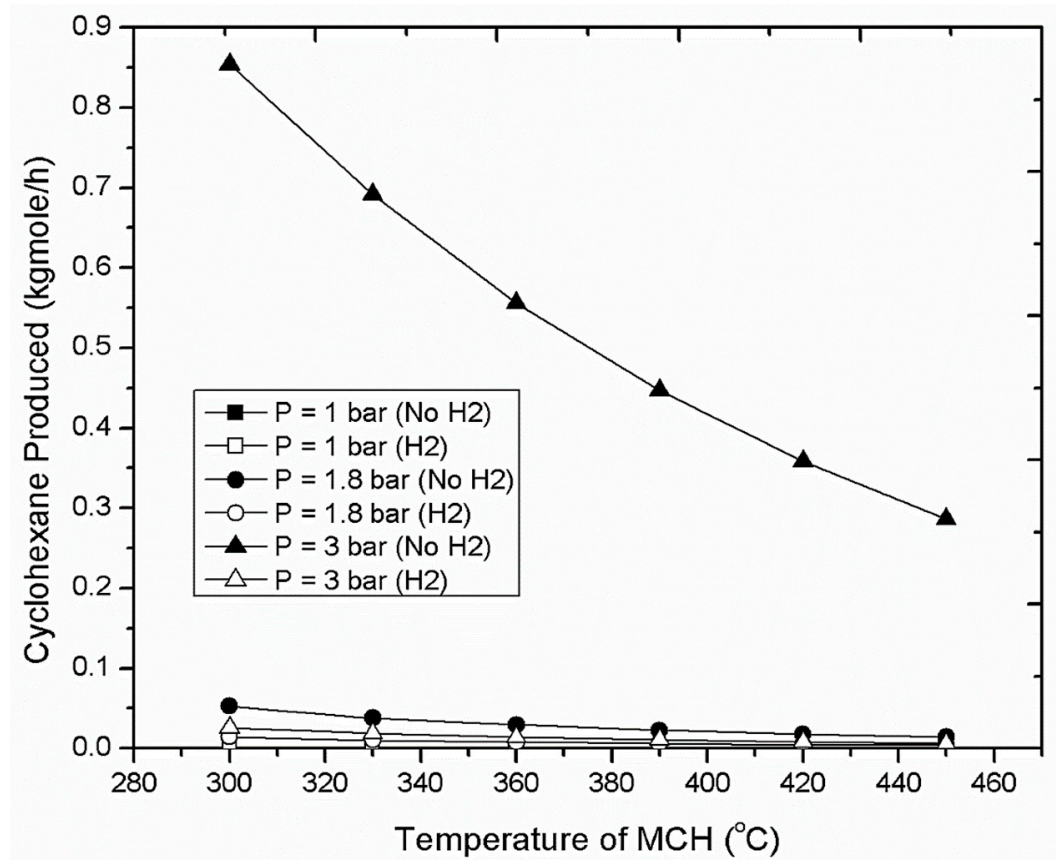

Figure 7. Effect of change in feed operating conditions on the cyclohexane flow rate.

With the decrease in pressure or increase in temperature, the cyclohexane dehydrogenation to benzene increases, therefore, the benzene is the main byproduct at low pressure and high temperature, in accordance with the experimental results of Usman et al. [34]. The trend is presented in Figure 8. 


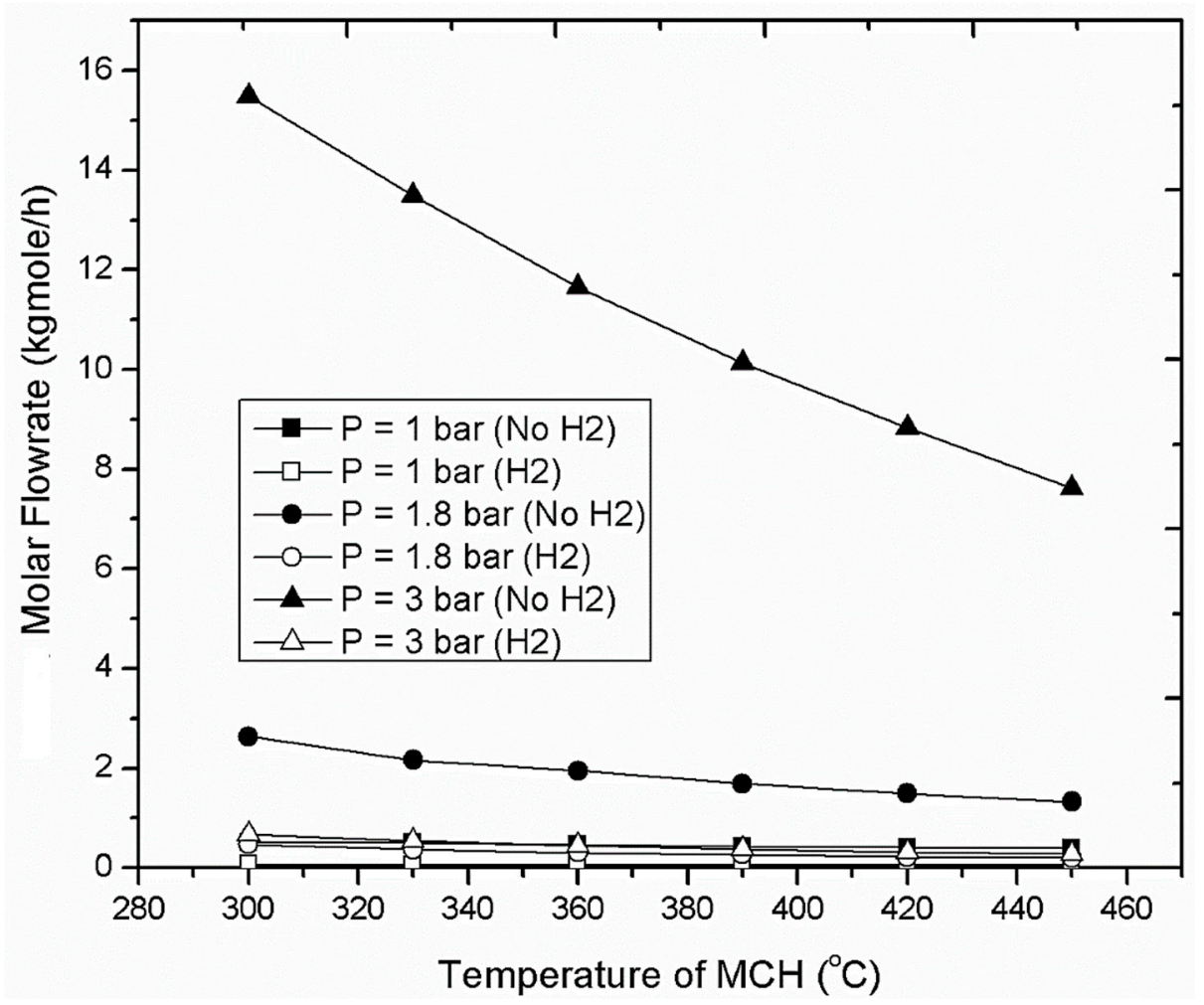

Figure 8. Effect of change in feed operating conditions on the benzene flow rate.

The rankings of the catalysts used in the dehydrogenation reactor, with varying conditions of temperature and pressure as demonstrated in Table 7, with 1 being the most effective and 6 being the least effective. The ranking of the catalysts has been decided, which is based on the percentage $\mathrm{MCH}$ conversion rate.

Table 7. Rankings of the catalyst for operating conditions.

\begin{tabular}{|c|c|c|c|}
\hline Catalyst Type & $P=1$ bar & $P=1.8$ bar & $P=3$ bar \\
\hline \multicolumn{4}{|c|}{ \% MCH Conversion (No Hydrogen in Feed) } \\
\hline Catalyst-1 & 3 & 3 & 3 \\
\hline Catalyst-2 & 5 & 5 & 6 \\
\hline Catalyst-3 & 1 & 1 & 1 \\
\hline Catalyst-4 & 4 & 4 & 4 \\
\hline Catalyst-5 & 2 & 2 & 2 \\
\hline Catalyst- 6 & 6 & 6 & 5 \\
\hline \multicolumn{4}{|c|}{$\%$ MCH Conversion (With Hydrogen in Feed) } \\
\hline Catalyst-1 & 3 & 3 & 4 \\
\hline Catalyst-2 & 5 & 5 & 6 \\
\hline Catalyst-3 & 1 & 1 & 1 \\
\hline Catalyst-4 & 4 & 4 & 3 \\
\hline Catalyst-5 & 2 & 2 & 2 \\
\hline Catalyst-6 & 6 & 6 & 5 \\
\hline
\end{tabular}

Notation 1 means comparatively best performance for studied parameters, and notation 6 means comparatively worst performance.

The overall ranking of the catalysts is presented in Table 8, with 1 being the most effective and 6 being the least effective. The ranking has been presented under both conditions, i.e., in the absence and presence of hydrogen in the reactor feed. The analysis reveals that the best catalyst understudy is catalyst-3, i.e., 1 wt. $\% \mathrm{Pt} / \theta-\mathrm{Al}_{2} \mathrm{O}_{3}$, followed by catalyst-5, i.e., 1 wt. $\% \mathrm{Pt} / \gamma-\mathrm{Al}_{2} \mathrm{O}_{3}$. As reported by 
Usman et al., these two catalysts have nearly comparable stability for 250 hours. The stability and activity of catalyst-1, i.e., $0.3 \mathrm{wt}$. $\% \mathrm{Pt} / \mathrm{Al}_{2} \mathrm{O}_{3}$, start decreasing just after 50 hours [13]. So, this catalyst cannot be used for the process. The use of catalyst-4, i.e., $1 \mathrm{wt}$ \% Pt/ $\beta$-Zeolite, leads to comparatively increased production of byproducts, thus conversion with this catalyst is not clean. Furthermore, the stability and activity of the catalyst starts decreasing just after 30 hours. Therefore, this catalyst cannot be used for the simulation system $[20,21]$. The properties of catalyst-6, i.e., $0.3 \mathrm{wt}$. $\% \mathrm{Pt}-\mathrm{Re} / \mathrm{Al}_{2} \mathrm{O}_{3}$, are like that of catalyst- 1 . Therefore, catalyst- 3 and catalyst- 5 are superior choices for this system.

Table 8. Final rankings of the dehydrogenation reactor catalysts.

\begin{tabular}{|c|c|c|c|}
\hline Catalyst Number & Catalyst Type & Rankings ( $\mathrm{No}_{2}$ in the Feed) & Ranking (with $\mathrm{H}_{2}$ in the Feed) \\
\hline Catalyst-1 & $\begin{array}{c}0.3 \text { wt. } \% \\
\mathrm{Pt} / \gamma-\mathrm{Al}_{2} \mathrm{O}_{3}\end{array}$ & 3 & 3 \\
\hline Catalyst-2 & Sulfided $\mathrm{Pt} / \mathrm{Al}_{2} \mathrm{O}_{3}$ & 5 & 5 \\
\hline Catalyst-3 & 1 wt. $\% \mathrm{Pt} / \theta-\mathrm{Al}_{2} \mathrm{O}_{3}$ & 1 & 1 \\
\hline Catalyst- 4 & $\begin{array}{c}1 \text { wt. } \% \\
\mathrm{Pt} / \beta \text {-Zeolite }\end{array}$ & 4 & 4 \\
\hline Catalyst-5 & 1 wt. $\% \mathrm{Pt} / \gamma-\mathrm{Al}_{2} \mathrm{O}_{3}$ & 2 & 2 \\
\hline Catalyst-6 & $\begin{array}{c}0.3 \text { wt. } \% \mathrm{Pt}+ \\
\mathrm{Re} / \mathrm{Al}_{2} \mathrm{O}_{3}\end{array}$ & 6 & 6 \\
\hline
\end{tabular}

Notation 1 means comparatively best performance for studied parameters, and notation 6 means comparatively worst performance.

The percentage conversion rate of $\mathrm{MCH}$ for both catalysts are nearly the same. Thus, for the selection of the catalyst for the simulation study, various parameters were investigated, i.e., surface area, stability, and manufacturing cost. The surface area (BET value) of catalyst- 5 is high, i.e., $208 \mathrm{~m}^{2} / \mathrm{g}$, while for catalyst-3, the value is $99.1 \mathrm{~m}^{2} / \mathrm{g}$. The cost of preparation of catalyst- 5 is comparatively low as compared to the catalyst-3, i.e., catalyst- 5 is prepared at low temperature, while catalyst- 3 is prepared at above $700{ }^{\circ} \mathrm{C}$. Furthermore, both these catalysts have nearly the same stability. Therefore, catalyst- 5 has been selected for the study. The following kinetic data has been used for the catalyst- 5 in Equations (1)-(4) [22]:

$$
\begin{gathered}
-r=\frac{40.907 \cdot k \cdot p_{A} \cdot\left(1-\frac{p_{B} \cdot p_{C}^{3}}{K \cdot p_{A}}\right)}{1+40.907 \cdot p_{A}+22 \cdot 194 \cdot p_{B}+K^{\prime} \cdot p_{B} \cdot p_{C}^{2}}\left(1-1.471 . t_{d}\right) \\
K=3600 \cdot \exp \left(\frac{-217650}{R}\left(\frac{1}{T}-\frac{1}{650}\right)\right) \\
k=4.064 \times 10^{-5} \cdot \exp \left(7.652 \cdot\left(1-\frac{617.2}{T}\right)\right) \\
K^{\prime}=6.688 \cdot \exp \left(-24.038\left(1-\frac{617.2}{T}\right)\right)
\end{gathered}
$$

A detailed investigation of the system under various operational conditions, followed by ranking, presents that the optimum operating conditions for the operation of the dehydrogenation reaction are:

- Temperature range $=360-390^{\circ} \mathrm{C}$

- $\quad$ Pressure range $=1.8-2$ bar

- Addition/concentration of hydrogen, i.e., $\mathrm{H}_{2} / \mathrm{MCH}=0.5$ (by weight)

Percentage of $\mathrm{MCH}$ conversion increases with the increase in the feed temperature. However, the increase in temperature leads to decreased operational time of the catalyst, decreasing its activity and stability span. Therefore, the operating range of $360-390^{\circ} \mathrm{C}$ is selected. The increase of pressure decreases the rate of conversion in a significant way. Therefore, an optimized pressure range of 1.8-2 bars is selected. Since, the reaction is operating at a high temperature, the catalyst degradation increases than operating at a lower temperature. However, operation at low temperature leads to decreased 
conversion of the $\mathrm{MCH}$. To overcome this situation, hydrogen addition is carried out with the feed to allow operation of the system at high temperature, improving the stability and activity of the system, by avoiding coke formation on the surface of the catalyst.

\section{Conclusions}

The parametric study was carried out on Aspen HYSYS v. 9.0 to investigate the dehydrogenation rate of methylcyclohexane for determining the optimum operating conditions and catalyst. The decrease in pressure and increase in temperature resulted in high percentage conversion of methylcyclohexane dehydrogenation and reduced quantities of byproducts. The optimum operating conditions selected for the process were $360^{\circ} \mathrm{C}$ and 1.8 bars. The $\mathrm{H}_{2} / \mathrm{MCH}$ ratio in the feed was maintained as 0.5 for the dehydrogenation system. Although the addition of the hydrogen resulted in a slightly lower methylcyclohexane dehydrogenation rate, it promoted the catalyst activation. The best catalyst found was $1 \mathrm{wt}$. $\% \mathrm{Pt} / \gamma-\mathrm{Al}_{2} \mathrm{O}_{3}$, as its manufacturing cost was comparatively lower, and it has a comparatively higher surface area (BET value). The cyclohexane was the main byproduct at high pressure and low temperature, while benzene was found as the main byproduct at the low pressure and high temperature in the dehydrogenation reactor.

Author Contributions: All authors contributed equally to this work. All authors wrote, reviewed, and commented on the manuscript. All authors have read and agreed to the published version of the manuscript.

Funding: This research did not receive any specific grants from funding agencies in the public, commercial, or not-for-profit sectors.

Acknowledgments: The authors are thankful to COMSATS University Islamabad, Lahore Campus for providing access to the registered version of Aspen HYSYS v. 9.0.

Conflicts of Interest: The authors declare no conflicts of interest.

\section{Nomenclature}

$\mathrm{T}$

$\mathrm{P}$

LOHC

MTH

$\mathrm{MCH}$

DBT

PDBT

BET

$-\mathrm{r}$

$\mathrm{k}$

K

$\mathrm{K}^{\prime}$

$t_{d}$

$k W h_{x} / k W h_{\text {hyd }}$

PL

LHHW
Temperature $\left({ }^{\circ} \mathrm{C}\right)$

Pressure (bar)

Liquid organic hydrogen carriers

Methylcyclohexane-toluene-hydrogen

Methylcyclohexane

Dibenzyl toluene

Perhydro-dibenzyl toluene

Brunauer-Emmett-Teller

Rate of dehydrogenation reaction $\left(\mathrm{mol} \mathrm{kg}^{-1} \mathrm{~s}^{-1}\right)$

Rate constant for the $\mathrm{MCH}$ dehydrogenation reaction

Equilibrium constant of $\mathrm{MCH}$ dehydrogenation

reaction, bar $^{3}$

Lumped equilibrium constant, $\mathrm{bar}^{-3}$

Online reaction deactivation time, $\mathrm{s}$

Calculation of the energy losses (Ex) occurring during

a process step $\left(k W h_{x}\right)$ relative to the amount of

transported energy $\left(\mathrm{kWh}_{\text {hyd }}\right.$ ) (expressed by the lower

heating value of the hydrogen, LHV, $33 \mathrm{kWh} / \mathrm{kg}$ )

Power Law

Langmuir-Hinshelwood-Hougen-Watson

\section{References}

1. Müller, K.; Arlt, W. Status and Development in Hydrogen Transport and Storage for Energy Applications. Energy Technol. 2013, 1, 501-511. [CrossRef]

2. Mazloomi, K.; Gomes, C. Hydrogen as an energy carrier: Prospects and challenges. Renew. Sustain. Energy Rev. 2012, 16, 3024-3033. [CrossRef] 
3. Teichmann, D.; Arlt, W.; Wasserscheid, P. Liquid Organic Hydrogen Carriers as an efficient vector for the transport and storage of renewable energy. Int. J. Hydrog. Energy 2012, 37, 18118-18132. [CrossRef]

4. Nicoletti, G.; Arcuri, N.; Nicoletti, G.; Bruno, R. A technical and environmental comparison between hydrogen and some fossil fuels. Energy Convers. Manag. 2015, 89, 205-213. [CrossRef]

5. Preuster, P.; Papp, C.; Wasserscheid, P. Liquid Organic Hydrogen Carriers (LOHCs): Toward a Hydrogen-free Hydrogen Economy. Acc. Chem. Res. 2017, 50, 74-85. [CrossRef] [PubMed]

6. Müller, K.; Thiele, S.; Wasserscheid, P. Evaluations of Concepts for the Integration of Fuel Cells in Liquid Organic Hydrogen Carrier Systems. Energy Fuels 2019, 33, 10324-10330. [CrossRef]

7. Wijayanta, A.T.; Oda, T.; Purnomo, C.W.; Kashiwagi, T.; Aziz, M. Liquid hydrogen, methylcyclohexane, and ammonia as potential hydrogen storage: Comparison review. Int. J. Hydrog. Energy 2019, 44, 15026-15044. [CrossRef]

8. Preuster, P.; Fang, Q.; Peters, R.; Deja, R.; Nguyen, V.N.; Blum, L.; Stolten, D.; Wasserscheid, P. Solid oxide fuel cell operating on liquid organic hydrogen carrier-based hydrogen-making full use of heat integration potentials. Int. J. Hydrog. Energy 2018, 43, 1758-1768. [CrossRef]

9. Michalska, K.; Kowalik, P.; Konkol, M.; Próchniak, W.; Stołecki, K.; Słowik, G.; Borowiecki, T. The effect of copper on benzene hydrogenation to cyclohexane over $\mathrm{Ni} / \mathrm{Al}_{2} \mathrm{O}_{3}$ catalyst. Appl. Catal. A Gen. 2016, 523, 54-60. [CrossRef]

10. Zhu, Q.L.; Xu, Q. Liquid organic and inorganic chemical hydrides for high-capacity hydrogen storage. Energy Environ. Sci. 2015, 8, 478-512. [CrossRef]

11. Modisha, P.M.; Ouma, C.N.M.; Garidzirai, R.; Wasserscheid, P.; Bessarabov, D. The Prospect of Hydrogen Storage Using Liquid Organic Hydrogen Carriers. Energy Fuels 2019, 33, 2778-2796. [CrossRef]

12. Hu, P.; Fogler, E.; Diskin-Posner, Y.; Iron, M.A.; Milstein, D. A novel liquid organic hydrogen carrier system based on catalytic peptide formation and hydrogenation. Nat. Commun. 2015, 6, 6859. [CrossRef] [PubMed]

13. Usman, M.R.; Cresswell, D.L. Options for on-board use of hydrogen based on the methylcyclohexane-totoluene-hydrogen system. Int. J. Green Energy 2013, 10, 177-189. [CrossRef]

14. Sotoodeh, F.; Smith, K.J. An overview of the kinetics and catalysis of hydrogen storage on organic liquids. Can. J. Chem. Eng. 2013, 91, 1477-1490. [CrossRef]

15. Taube, M.; Rippin, D.W.T.; Cresswell, D.L.; Knecht, W. A system of hydrogen-powered vehicles with liquid organic hydrides. Int. J. Hydrog. Energy 1983, 8, 213-225. [CrossRef]

16. Jothimurugesan, K.; Bhatia, S.; Srivastava, R.D. Kinetics of dehydrogenation of methylcyclohexane over a platinum-rhenium-alumina catalyst in the presence of added hydrogen. Ind. Eng. Chem. Fundam. 1985, 24, 433-438. [CrossRef]

17. Mizsey, P.; Cuellar, A.; Newson, E.; Hottinger, P.; Truong, T.B.; von Roth, F. Fixed bed reactor modelling and experimental data for catalytic dehydrogenation in seasonal energy storage applications. Comput. Chem. Eng. 1999, 23, S379-S382. [CrossRef]

18. Usman, M.R. Methylcyclohexane dehydrogenation over commercial $0.3 \mathrm{Wt} \% \mathrm{Pt} / \mathrm{Al}_{2} \mathrm{O}_{3}$ catalyst. Proc. Pak. Acad. Sci. 2011, 48, 13-17.

19. Usman, M.R.; Aslam, R.; Alotaibi, F. Hydrogen Storage in a Recyclable Organic Hydride: Kinetic Modeling of Methylcyclohexane Dehydrogenation Over $1.0 \mathrm{wt} \% \mathrm{Pt} / \theta-A 12 \mathrm{O}$. Energy Sources Part A Recovery Util. Environ. Eff. 2011, 33, 2264-2271. [CrossRef]

20. Usman, M.R. The Catalytic Dehydrogenation of Methylcyclohexane over Monometallic Catalysts for On-board Hydrogen Storage, Production, and Utilization. Energy Sources Part A Recovery Util. Environ. Eff. 2011, 33, 2231-2238. [CrossRef]

21. Usman, M.R.; Alotaibi, F.M.; Aslam, R. Dehydrogenation-hydrogenation of methylcyclohexane-toluene system on $1.0 \mathrm{wt} \%$ Pt/zeolite beta catalyst. Prog. React. Kinet. Mech. 2015, 40, 353-366. [CrossRef]

22. Usman, M.R.; Cresswell, D.L. Prototype reactor simulation for on-board use of hydrogen in a hybrid MTH (methylcyclohexane-toluene-hydrogen)-gasoline system and a simplified dynamic modeling for the startup. Chem. Eng. Res. Des. 2015, 104, 125-138. [CrossRef]

23. Chen, Y.-R.; Tsuru, T.; Kang, D.-Y. Simulation and design of catalytic membrane reactor for hydrogen production via methylcyclohexane dehydrogenation. Int. J. Hydrog. Energy 2017, 42, 26296-26307. [CrossRef]

24. Wang, W.; Miao, L.; Wu, K.; Chen, G.; Huang, Y.; Yang, Y. Hydrogen evolution in the dehydrogenation of methylcyclohexane over $\mathrm{Pt} / \mathrm{CeMgAlO}$ catalysts derived from their layered double hydroxides. Int. J. Hydrog. Energy 2019, 44, 2918-2925. [CrossRef] 
25. Obara, S. Energy and exergy flows of a hydrogen supply chain with truck transportation of ammonia or methyl cyclohexane. Energy 2019, 174, 848-860. [CrossRef]

26. Juangsa, F.B.; Prananto, L.A.; Mufrodi, Z.; Budiman, A.; Oda, T.; Aziz, M. Highly energy-efficient combination of dehydrogenation of methylcyclohexane and hydrogen-based power generation. Appl. Energy 2018, 226, 31-38. [CrossRef]

27. Prananto, L.A.; Biddinika, M.K.; Aziz, M. Combined dehydrogenation and hydrogen-based power generation. Energy Procedia 2017, 142, 1603-1608. [CrossRef]

28. Vajda, S.; Pellin, M.J.; Greeley, J.P.; Marshall, C.L.; Curtiss, L.A.; Ballentine, G.A.; Elam, J.W.; Mucherie, S.C.; Redfern, P.C.; Mehmood, F.; et al. Subnanometre platinum clusters as highly active and selective catalysts for the oxidative dehydrogenation of propane. Nat. Mater. 2009, 8, 213-216. [CrossRef]

29. Kuo CTe Lu, Y.; Kovarik, L.; Engelhard, M.; Karim, A.M. Structure Sensitivity of Acetylene Semi-Hydrogenation on Pt Single Atoms and Subnanometer Clusters. ACS Catal. 2019, 9, 11030-11041.

30. Aquilanti, V.; Coutinho, N.D.; Carvalho-Silva, V.H. Kinetics of low-temperature transitions and a reaction rate theory from non-equilibrium distributions. Philos. Trans. R. Soc. A Math. Phys. Eng. Sci. 2017, 375. [CrossRef]

31. Chen, B.; Hoffmann, R.; Cammi, R. The Effect of Pressure on Organic Reactions in Fluids-A New Theoretical Perspective. Angew. Chem. Int. Ed. 2017, 56, 11126-11142. [CrossRef] [PubMed]

32. Pant, A.F.; Özkasikci, D.; Fürtauer, S.; Reinelt, M. The Effect of Deprotonation on the Reaction Kinetics of an Oxygen Scavenger Based on Gallic Acid. Front. Chem. 2019, 7, 680. [CrossRef] [PubMed]

33. Hamayun, M.H.; Hussain, M.; Maafa, I.M.; Aslam, R. Integration of hydrogenation and dehydrogenation system for hydrogen storage and electricity generation-simulation study. Int. J. Hydrog. Energy 2019, 44, 20213-20222. [CrossRef]

34. Usman, M.R.; Cresswell, D.L.; Garforth, A.A. By-Products Formation in the Dehydrogenation of Methylcyclohexane. Pet. Sci. Technol. 2011, 29, 2247-2257. [CrossRef]

(C) 2020 by the authors. Licensee MDPI, Basel, Switzerland. This article is an open access article distributed under the terms and conditions of the Creative Commons Attribution (CC BY) license (http://creativecommons.org/licenses/by/4.0/). 